\title{
Detrital chromite concentrations, nearshore Port au Port Bay, Newfoundland
}

\author{
M. Emory-Moore, W.J. Scott, L. Davis \\ Centre for Cold Ocean Resources Engineering (C-CORE), Memorial University of Newfoundland, \\ St. John's, Newfoundland A1B 3X5, Canada \\ and \\ S. Solomon \\ Atlantic Geoscience Centre, P.O. Box 1006, Dartmouth, Nova Scotia B2Y 4A2, Canada \\ Date Received December 10, 1991 \\ Date Accepted July 20, 1992
}

\begin{abstract}
A nearshore sediment sampling program was undertaken in Port au Port Bay, western Newfoundland. The objectives of the program were to map the distribution of detrital chromite in the seabed sediments and to evaluate the paleoenvironmental evolution of chromite-bearing sedimentary facies. Bottom sediments were found to be enriched in detrital chromite in an area adjacent to and parallel to the east shore of the bay, south of the mouth of the Fox Island River. During glaciation, chromite from the Lewis Hills ophiolite complex was incorporated in glacial materials. Post-glacial reworking of chromite-bearing sediments by fluvial and marine processes is observed in a number of sedimentary facies: fluvial sediments of the Fox Island River, a large outwash plain and marine-limit delta occurring near the mouth of Fox Island River, an erosional lag blanketing the outwash delta, and emergent and submergent beach terraces bordering a small coastal embayment south of Fox Island River. The relatively low wave energy of the Port au Port Bay area appears, however, to have precluded extensive placer development in all sedimentary facies.
\end{abstract}

Un programme d'échantillonage des sédiments côtiers fut entrepris dans la baie de Port-au-Port, dans l'ouest de Terre-Neuve. Les buts de ce programme étaient de cartographier la distribution de la chromite détritique dans les sédiments de fonds marin et d'évaluer l'évolution paléo-environnementale des faciès sédimentaires porteurs de chromite. Les sédiments de fond se sont révélés être enrichis en chromite détritique dans une zone adjacente et parallèle à la côte est de la baie, au sud de l'embouchure de la rivière de l'íle Fox. Pendant la glaciation, la chromite du complexe ophiolitique de Lewis Hills fut incorporée dans les matériaux glaciaires. Le remaniement post-glaciaire des sédiments porteurs de chromite par des processus fluviaux et marins est observé dans un certain nombre de faciès sédimentaires: les sédiments fluviaux de la rivière de l'île Fox, un sandur étendu et un delta de contact glaciaire situé près de l'embouchure de la rivière de l'île Fox, un gravier résiduel qui recouvre le sandur et des terrasses marines émergentes et submergées bordant une anse située au sud de la rivière de l'île Fox. L'énergie relativement basse des vagues de la région de Port-au-Port semble toutefois avoir empêché la formation de placers étendus dans tous les faciès sédimentaires.

[Traduit par le journal]

\section{INTRODUCTION}

Prerequisites for marine placer formation include the presence of a mineralized source terrain, the liberation of placer mineral grains through weathering of bedrock, a sustained supply of mineralized detritus to the marine environment and a depositional sink which is conducive to selective sorting of mineral grains. The premise of the present study is that these conditions are met in Port au Port Bay (Fig. 1): chromite-bearing ophiolites are exposed in the high-relief hinterland of the study area; bedrock in the area has been extensively eroded by glaciation, mass wasting and fluvial incision; the Fox Island River provides a transport corridor for mineralized sediment into Port au Port Bay; and the semienclosed character of Port au Port Bay acts as a geomorphic 'trap' for detrital chromite. Grades of $10 \% \mathrm{Cr}_{2} \mathrm{O}_{3}$ have been identified in beach sands at the mouth of Fox Island River (Hill and Ruest, 1980); however, no previous attempt has been made to assess the placer potential of the nearshore sediments. Results of detailed beach and nearshore sampling programs in Port au Port Bay are presented herein and are used to advance an interpretation of the paleoenvironmental evolution and succession of chromite-bearing sedimentary facies.

\section{The Study Area}

Port au Port Bay, located in western Newfoundland, is a structurally controlled semi-enclosed embayment (Fig. 1). The Bay is bordered to the west and south by a low to moderate relief coastline and to the east by a mountainous coastal region. The seabed morphology in Port au Port Bay is 


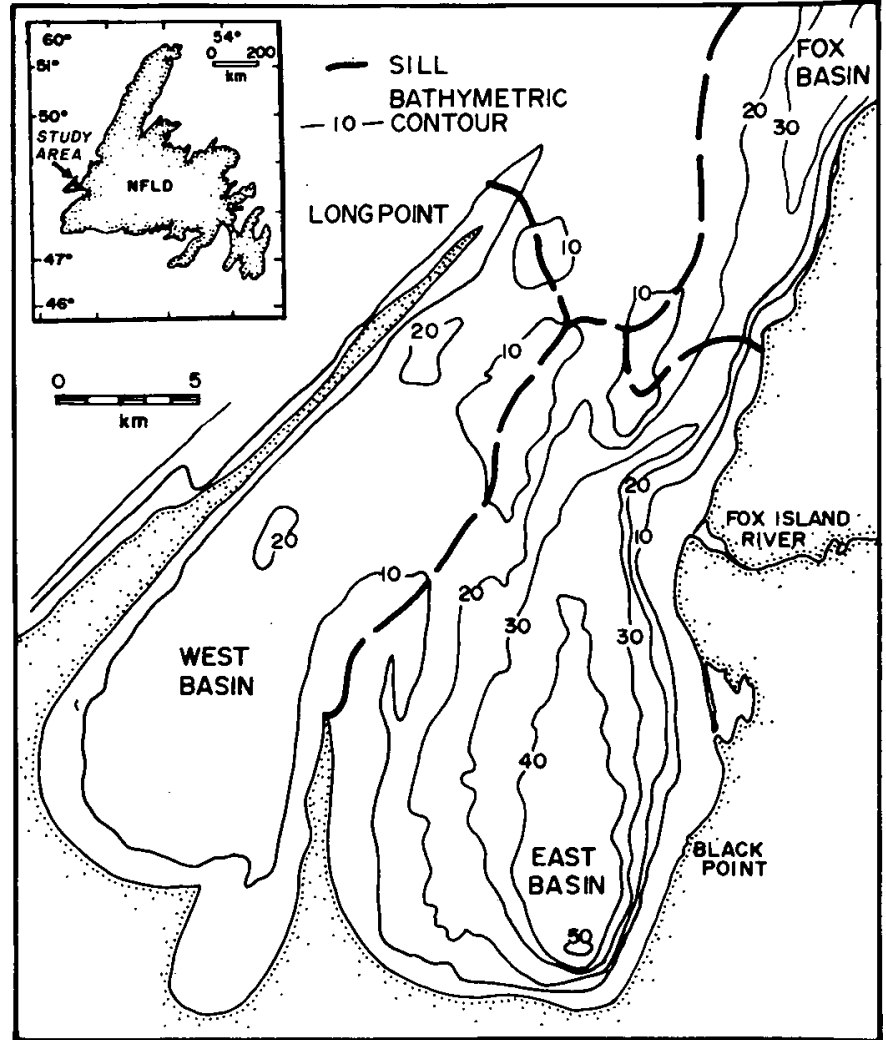

Fig. 1. Location and physiography of Port au Port Bay (contours in metres).

characterized by elongate basins trending north-south that range in maximum depths from 20 to $60 \mathrm{~m}$ with sill depths ranging from 14 to $35 \mathrm{~m}$ (Fig. 1).

\section{Bedrock geology of land areas}

The bedrock geology of the eastern Port au Port Bay area is illustrated in Figure 2. Cambrian to Middle Ordovician carbonate and clastic sequences are overlain by structural slices of Ordovician ophiolitic rocks (Williams, 1985). Nothing is known of the geology of the rocks underlying the bay itself.

The source of chromite in Port au Port Bay is the Lewis Hills ophiolite complex, located northeast of the bay. The ophiolite complex has been divided into two structural assemblages: the Coastal Complex and the Bay of Islands Complex (Karson, 1979; Fig. 2). The headwater tributaries of the Fox Island River drain the Bay of Islands Complex which is partially (about 50\%) composed of spinel-bearing harzburgite, tectonite and wherlite. $\mathrm{Cr}$-spinels are disseminated throughout the harzburgite and wherlite (2-3\%) and occur as isolated massive bands and layers (S. Dunsworth, personal communication, 1992). Chromite within one of the major sites of massive mineralization (Springers Hill occurrence) was found to be less than $2 \mathrm{~mm}$ in diameter and graded from 50 to $61 \% \mathrm{Cr}_{2} \mathrm{O}_{3}$ by weight in the richest sections (Dunsworth et al., 1986). Disseminated chromite also occurs within harzburgites of the Coastal Complex, although volumetri-

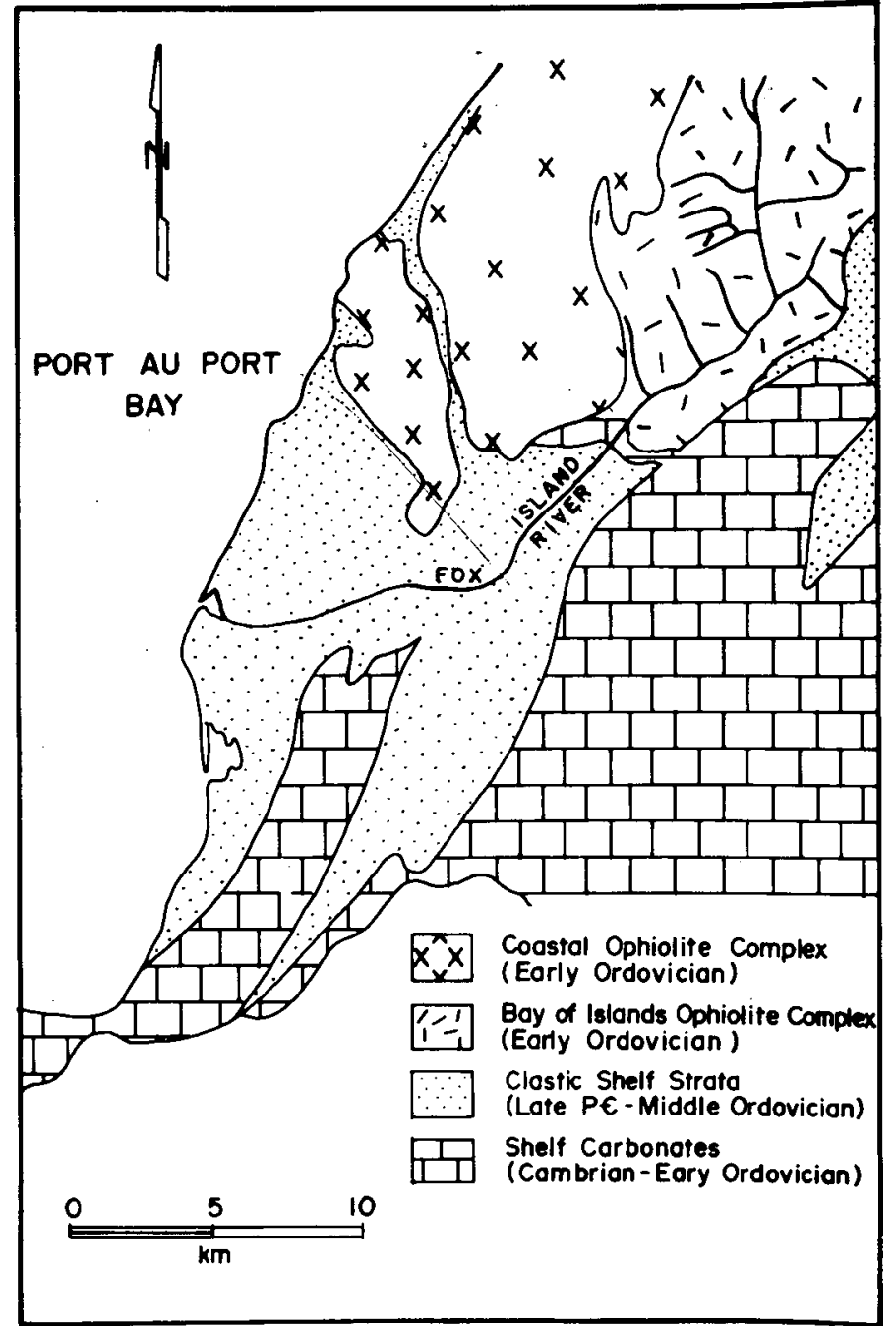

Fig. 2. Bedrock geology of the eastern Port au Port Bay area (modified from Cawood et al., 1988).

cally, harzburgites constitute less than $15 \%$ of the complex (S. Dunsworth, personal communication, 1992).

\section{Quaternary geology}

The study area was extensively glaciated during the Quaternary with valleys subjected to deep erosion and lowlands the focus of extensive sedimentation. Some of the highland areas were not significantly affected by glaciation and retain characteristics of unmodified pre-Quaternary peneplains (Grant, 1987). During the most recent glacial advance (Late Wisconsin) ice flow in the study area was from the west with maximum ice extent near present coastal limits (Grant, 1987).

Till, outwash sands and gravels and raised marine sediments are exposed in coastal bluffs of eastern Port au Port Bay (Fig. 3). The Fox Island River valley bears a cover of till and glacial-fluvial and fluvial sediment. A large glacial outwash plain/marine-limit delta, exposed in the lower reaches of the Fox Island River valley and the adjacent coastal bluffs, is composed of stratified, moderately sorted sand and gravel 


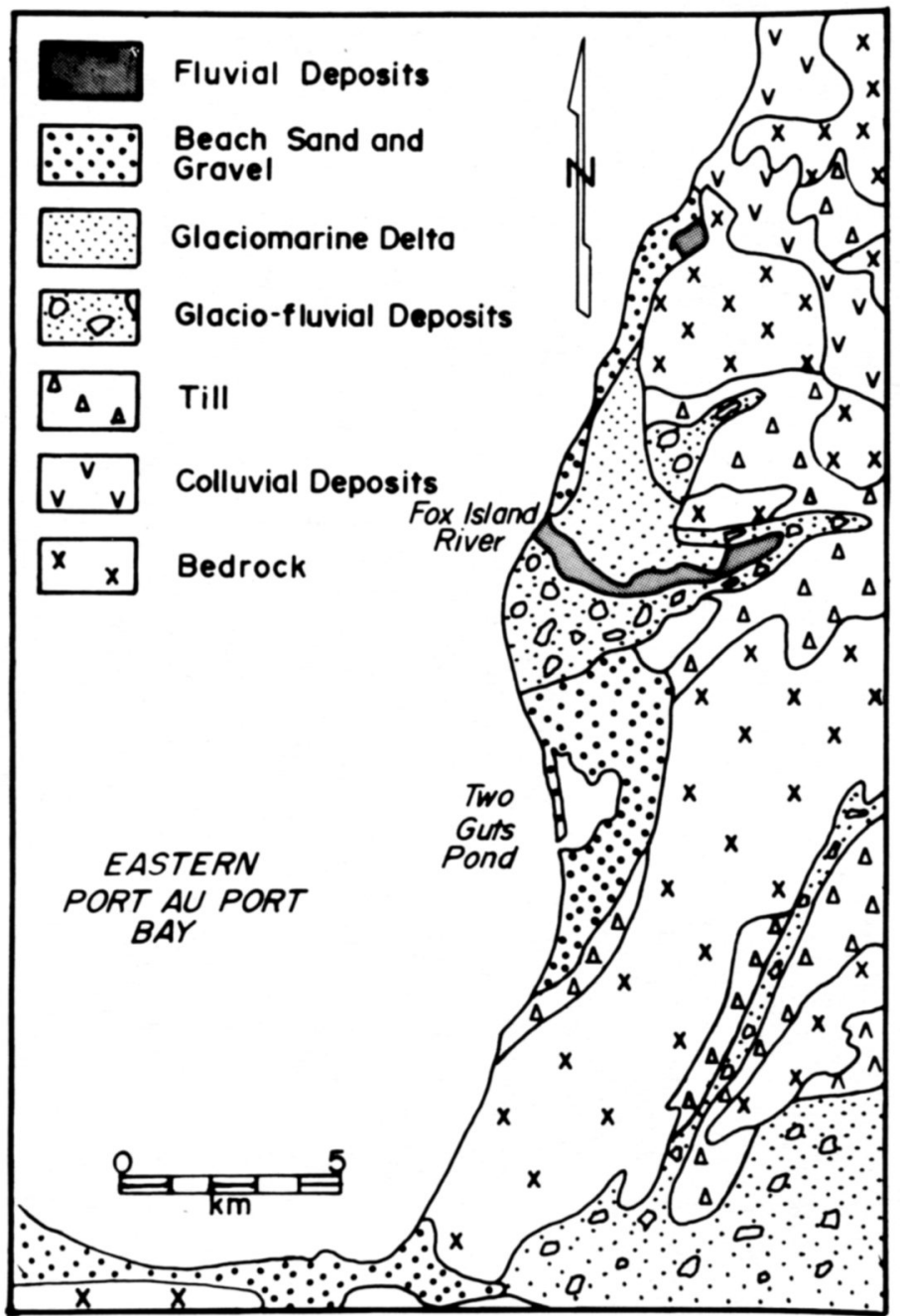

Fig. 3. Surficial geology of eastern Port au Port Bay (from Grant, 1991).

(Fig. 3). A large pocket of raised beach sand and gravel occurs in the Two Guts Pond area and is exposed along 4 to $6 \mathrm{~m}$ high bluffs bordering the shoreline north of the Pond.

Six seismostratigraphic units in Port au Port Bay collectively vary from $<1 \mathrm{~m}$ to over $60 \mathrm{~m}$ in thickness (Forbes $e t$ al., in press). Basal till, stratified drift and glaciomarine sand and silt are overlain by postglacial mud, deltaic sand and shoreface and tidal wedges of sand and gravel. The most extensive sequence of deltaic sands and gravels occurs offshore from Fox Island River where submerged terraces are still preserved.

The marine limit in the Port au Port Bay area is estimated to have been approximately $44 \mathrm{~m}$ above present sea level at around $14 \mathrm{ka}$ B.P. Relative sea level fell rapidly to a lowstand of about 25 to $27 \mathrm{~m}$ below present at about $9.5 \mathrm{ka} \mathrm{B.P.} \mathrm{and} \mathrm{has}$ subsequently undergone a slow continuous rise (Forbes et al., in press; Fig. 4).

\section{Sediment dispersal}

Present sediment dispersal within the coastal zone of

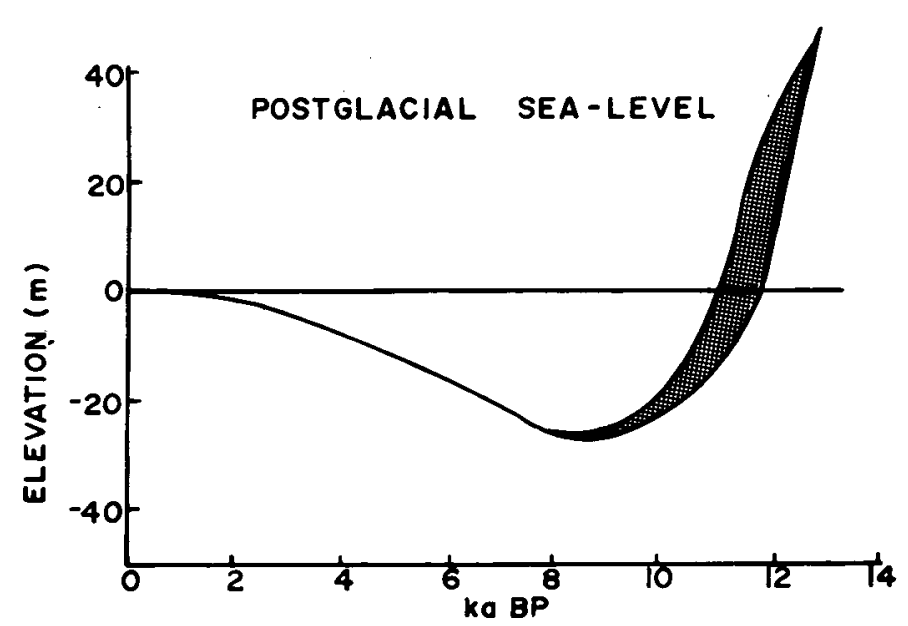

Fig. 4. Relative sea-level curve for Port au Port Bay (from Forbes et al., in press).

Port au Port Bay appears to be governed by local storm waves and associated longshore current processes. It is unlikely that long-period, ocean-generated swells are important features of the wave climate because of the sheltered, limited fetch conditions. During the summer, nearshore sediment transport in the vicinity of Fox Island River is low. Throughout the year transport of sediment to the north is relatively small and constant; most of the sediment transport occurs during the ice-free winter months (i.e., November to February) with a net transport to the south (Woodward-Clyde Consultants, 1982). The southward orientation of coastal spits and bars along the eastern shore of Port au Port Bay also indicates a net movement of sediment to the south.

\section{Methods of Sampling and Analysis}

The sample data presented in this paper were collected during two field programs. In the fall of 1989 a Shipek grab sampler was used to collect over 150 surficial seabed samples (Fig. 5), and a del Norte Trisponder navigation system was used to determine sample positions. The samples are representative of the upper 10 to $15 \mathrm{~cm}$ of the seabed and are approximately $0.02 \mathrm{~m}^{3}$ in volume. Early in the winter of 1990 , 24 bore holes were drilled from the ice in water depths of 0.5 to $7 \mathrm{~m}$ using a hand-held power auger and a percussion drill (Fig. 5). The core diameter was about $7 \mathrm{~cm}$. Stratigraphic samples measuring $25 \mathrm{~cm}$ in length were collected at borehole sampling intervals of $50 \mathrm{~cm}$. In addition, 30 surficial grab samples were collected using a fence post auger. Sample locations were determined using air-photos and compass bearings.

A split of each sample was dry sieved through a bank of four sieves measuring $2 \mathrm{~mm}, 0.5 \mathrm{~mm}, 0.25 \mathrm{~mm}$ and 0.063 $\mathrm{mm}$. Direct-coupled plasma (DCP) emission spectrometry and XRF were used for the analysis of trace-metals in $50 \mathrm{~g}$ splits of the 1989 suite of grab samples. The major oxide and trace-metal content of the samples collected during the 1990 survey were analyzed using inductively-coupled plasma (ICP) 


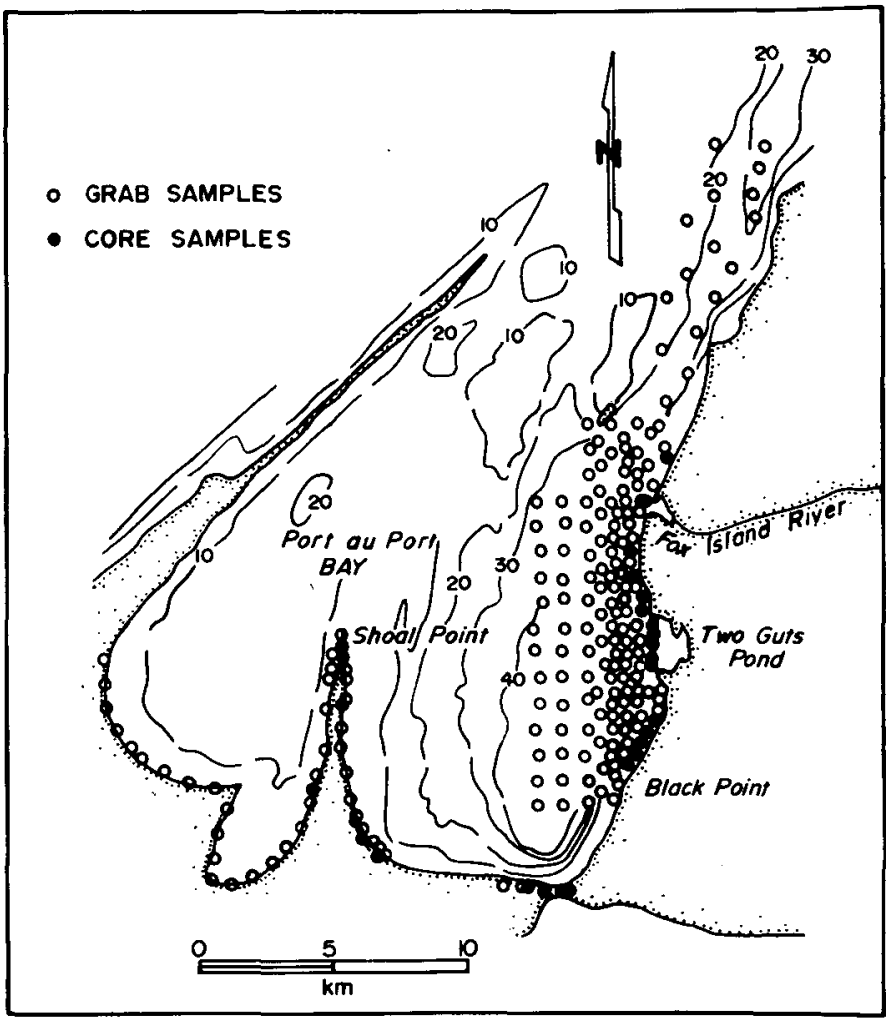

Fig. 5. Sample locations.

whole-rock analysis. Energy dispersive $\mathrm{X}$-ray analysis was used to examine the elemental composition of selected chromite grains.

\section{Results}

\section{Sediment texture}

The surficial sediments are divided into four textural classes: sandy mud, muddy sand, gravelly sand and sandy gravel (Fig. 6). In general, the grain size of the seabed sediments increases with decreasing water depths. Coarse sand and gravel are restricted to water depths of less than $5 \mathrm{~m}$, except where they occur in isolated pockets on submerged bedrock scarps and where coarse-grained glacial sediment has been reworked, armouring the seabed with a gravel lag. For example, the distribution of gravel-bearing sediment in water depths of up to $20 \mathrm{~m}$ off the mouth of Fox Island River is controlled by outcrops of the glacial outwash/delta discussed above and is not the result of modern sedimentation processes.

Moderately to well-sorted muddy sand occurs in water depths between 10 and $30 \mathrm{~m}$, with the most extensive exposure occurring in a belt $8 \mathrm{~km}$ long offshore from Two Guts Pond. Muds are restricted to deeper basinal areas in water depths greater than $25 \mathrm{~m}$.

An upper unit composed of moderately to well-sorted sands and gravels characterizes all the beach and nearshore

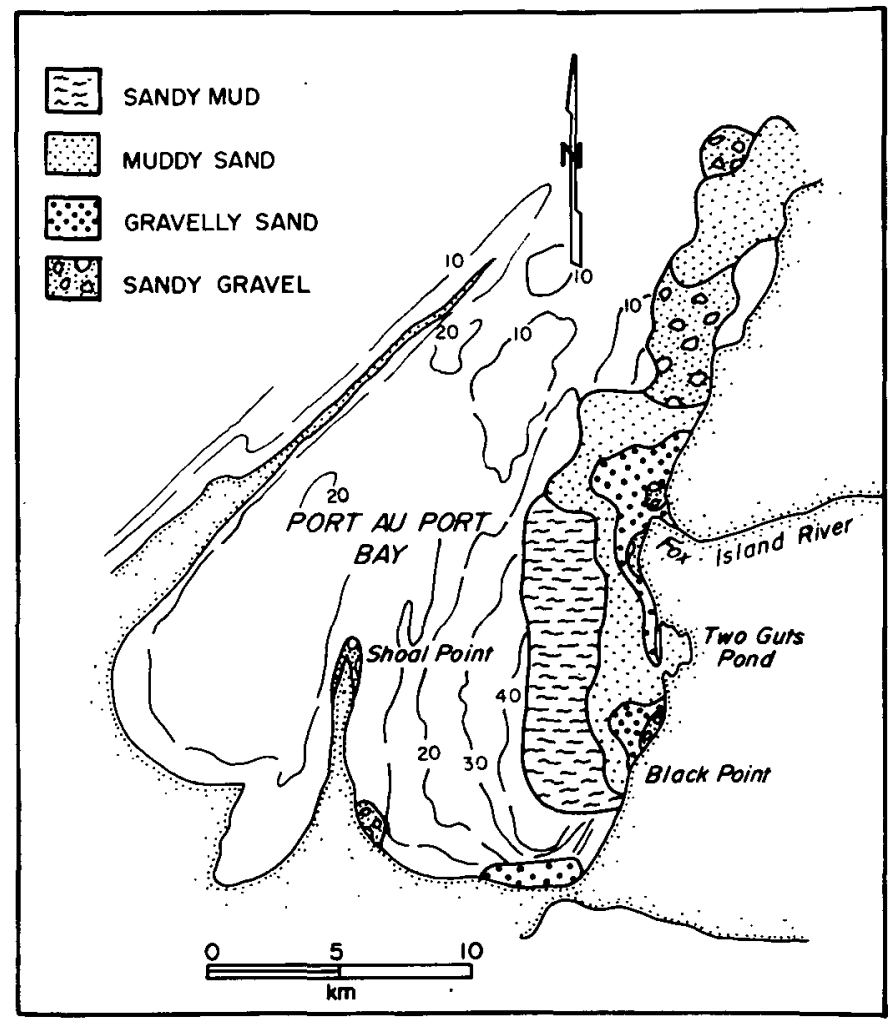

Fig. 6. Grouping of surficial sediments by texture.

core samples (Fig. 7). The sand and gravel unit ranges in thickness from 0.2 to $>5 \mathrm{~m}$ and is underlain by either bedrock, diamicton or massive muds.

\section{Sediment geochemistry}

The geochemical data from the 1989 sample suite were ranked and then clustered using a $\mathbf{k}$-means cluster analysis. Three distinct clusters were identified (Table 1a). The first cluster is characterized by a strong association of $\mathrm{Mg}, \mathrm{Cr}, \mathrm{Fe}$ and $\mathrm{Ni}$. The second and third clusters are characterized by an association of $\mathrm{Fe}, \mathrm{Zr}$ and $\mathrm{Ba}$, and $\mathrm{Fe}$ and $\mathrm{Ba}$ respectively. Discriminant analysis confirmed the cluster grouping, with about 10 to $15 \%$ overlap between the first two clusters, and 5 to $10 \%$ overlap between the third cluster and the other two. The overall classification rate for the cluster analysis was $70 \%$.

The geochemistry of the surficial sediments, as revealed in the geochemical clusters, exhibits marked spatial trends which appear to be related, at least in part, to bedrock provenance (Fig. 8). For example, samples characterized by an association of, and relative enrichment in, $\mathrm{Mg}, \mathrm{Fe}, \mathrm{Cr}$ and $\mathrm{Ni}$ (Group 1) occur almost exclusively in the nearshore zone extending from Fox Island River to Black Point. This elemental association is characteristic of an ophiolitic source terrane.

The samples exhibiting an $\mathrm{Fe}, \mathrm{Zr}$ and $\mathrm{Ba}$ association (Group 2) occur to the north of Fox Island River (Fig. 8). No 


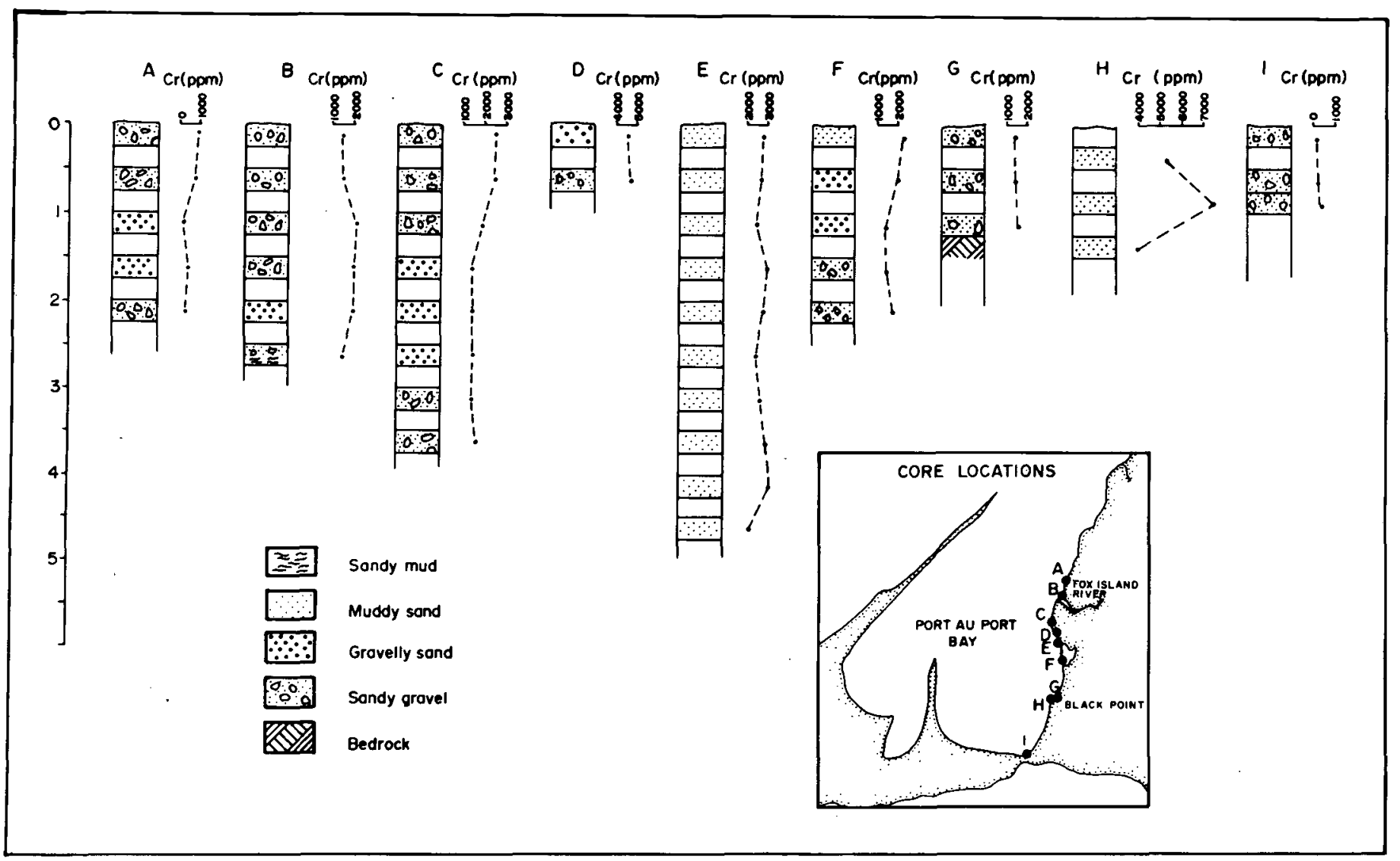

Fig. 7. Texture and $\mathrm{Cr}$ content of selected cores.

Table 1a. Mean concentration of elements within the geochemical clusters, 1989 samples.

Number

$\begin{array}{lllllllll}\text { of } & \mathrm{Sr} & \mathrm{Ca} & \mathrm{Cr} & \mathrm{Mg} & \mathrm{Fe} & \mathrm{Ni} & \mathrm{Ba} & \mathrm{Zr}\end{array}$

$\begin{array}{llllllllll}\text { Cluster Samples } & (\mathrm{ppm}) & (\mathrm{ppm}) & (\mathrm{ppm}) & (\mathrm{ppm}) & (\mathrm{ppm}) & (\mathrm{ppm}) & (\mathrm{ppm}) & (\mathrm{ppm})\end{array}$

\begin{tabular}{rrrrrrrrrr}
\hline 1 & 59 & NA & NA & 1728 & 69400 & 40066 & 308 & 327 & 138 \\
2 & 46 & NA & NA & 610 & 26742 & 9971 & 153 & 174 & 108 \\
3 & 54 & NA & NA & 643 & 44444 & 40037 & 169 & 509 & 154 \\
\hline
\end{tabular}

Table 1b. Mean concentration of elements within the geochemical clusters, 1990 samples.

$\begin{array}{ccccccccr}\begin{array}{c}\text { Number } \\ \text { of }\end{array} & \begin{array}{c}\mathrm{Sr} \\ \text { Samples }\end{array}\left(\begin{array}{c}\mathrm{Ca} \\ (\mathrm{ppm})\end{array}\right. & \begin{array}{c}\mathrm{Cr} \\ (\mathrm{ppm})\end{array} & \begin{array}{c}\mathrm{Mg} \\ (\mathrm{ppm})\end{array} & \begin{array}{c}\mathrm{Fe} \\ (\mathrm{ppm})\end{array} & \begin{array}{c}\mathrm{Ni} \\ (\mathrm{ppm})\end{array} & \begin{array}{c}\mathrm{Ba} \\ (\mathrm{ppm})\end{array} & \begin{array}{c}\mathrm{Zr} \\ (\mathrm{ppm})\end{array} \\ 25 & 106 & 3146 & 2257 & 92400 & 44690 & 578 & 222 & 83 \\ 17 & 192 & 45000 & 163 & 16200 & 25200 & 13 & 966 & \text { NA }\end{array}$




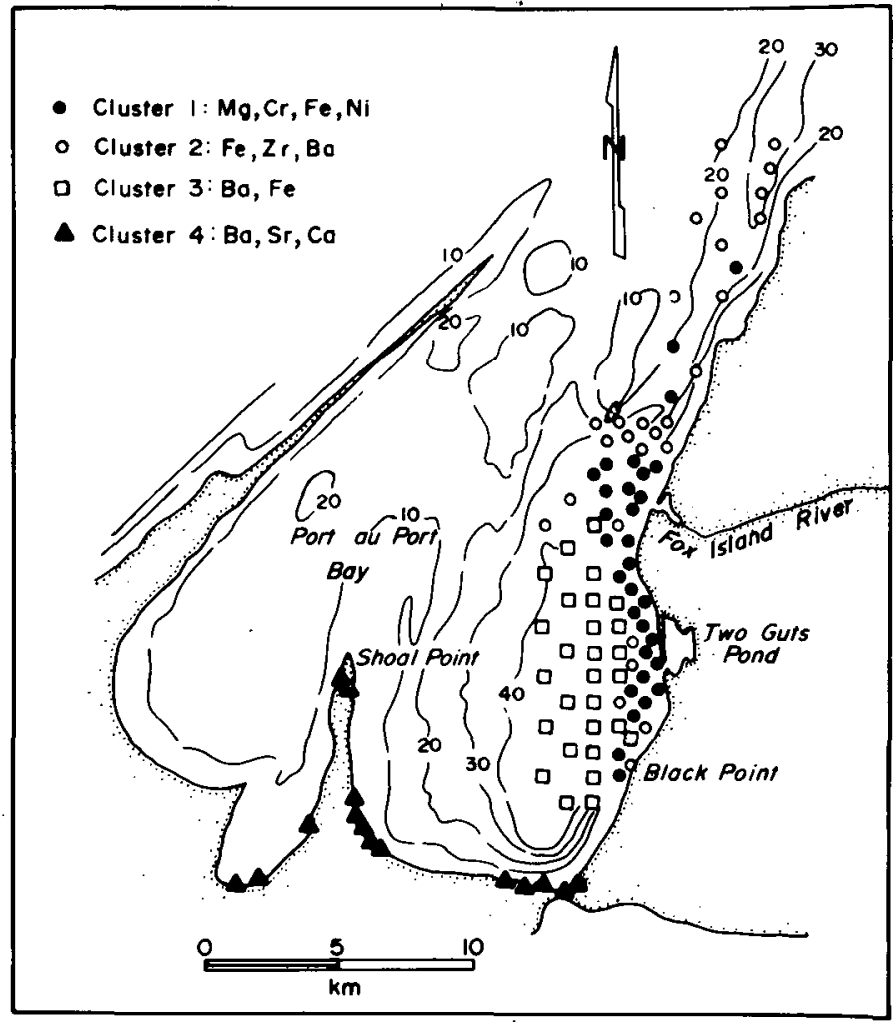

Fig. 8. Grouping of surficial sediments by geochemistry.

singular source terrane can be distinguished for this suite of elements. A mixture of source rocks, including ophiolitic and clastic rocks, is probable.

Sediments bearing $\mathrm{a} \mathrm{Ba}$ and $\mathrm{Fe}$ association (Group 3) are closely associated with basinal mud facies. This geochemical signature reflects the clay mineralogy and cannot be interpreted in terms of discrete source terrane.

Geochemical analysis of the 1990 sediment suite included both trace element and major oxide determinations. These data were also subjected to cluster analysis; the results are shown in Table lb. Two distinct clusters were identified. The first appears to be a subset of Group 1 from the 1990 sediment suite work with a close association of $\mathrm{Cr}, \mathrm{Mg}, \mathrm{Fe}$ and $\mathrm{Ni}$. The second (Group 4 ) is represented by an association of, and enrichment in, $\mathrm{Ba}, \mathrm{Sr}$ and $\mathrm{Ca}$; sediments which fall into this group occur along the south coast of Port au Port Bay, including the flanks of Shoal Point (Fig. 8). These samples are spatially associated with the Middle Ordovician clastic and carbonate coastal rock suite (Fig. 2); hence $\mathrm{Ca}$ and Sr within the seabed sediments are likely derivatives of carbonate rocks, whereas $\mathrm{Ba}$ may be a residual product of limestone weathering. Concentrations of these elements fall to background levels in areas where carbonate rocks are not present in the coastal rock suite.

Analysis of borehole samples revealed little vertical variation in geochemical signature within the upper sand and gravel unit. This lack of variation suggests that sediment sources and depositional processes have remained relatively constant over the time span represented by this unit.

\section{Chromium distribution}

A contour map of $\mathrm{Cr}$ concentrations within the surficial sediment suite was constructed using a weighted average of nearest neighbour sample points (Fig. 9). The contour intervals were chosen to reflect natural breakpoints in the cumulative frequency curve for $\mathrm{Cr}(\mathrm{ppm})$.

Cr-bearing surficial sediments occur along much of the eastern shore of Port au Port Bay and are most concentrated within a subdued coastal embayment which extends from just south of Fox Island River to Black Point (referred to here as the "Two Guts Pond embayment"; Fig. 9). Cr concentrations within the surficial sediments of the Two Guts Pond embayment exceed $1800 \mathrm{ppm}$ over an area of $8.6 \mathrm{~km}^{2}$ and in some areas extend to a depth of greater than $5 \mathrm{~m}$ (e.g., Core E; Fig. 7). The highest concentration of $\mathrm{Cr}$ was found off Black Point where concentrations reach $7439 \mathrm{ppm}$ and average $5644 \mathrm{ppm}$ over $1.4 \mathrm{~m}$.

The elevated concentrations of $\mathrm{Cr}$ identified off the mouth of Fox Island River occur within lag gravels of the large outwash/delta complex. Particulate chromite has most likely become enriched in the gravel through sediment deflation and contemporaneous grain entrapment. The highest concentrations of $\mathrm{Cr}$ are thus apt to occur in the reworked surficial layer. $\mathrm{Cr}$ exhibits a patchy, lower grade distribution in the area north of Fox Island River. The nearshore sediments in this area are derived, at least in part, from mass wasting of $\mathrm{Cr}$-bearing bedrock cliffs.

Chromitiferous sands were also identified in the raised marine sediments around Two Guts Pond. Four samples collected from raised shoreface sand and gravel were found to contain from 1200 to $10300 \mathrm{ppm}$ Cr.

Particulate chromite in all areas was found to be most abundant in the fine sand fraction (0.063-0.25 mm). In general, the chromite is characterized by a $\mathrm{Cr}$ :Fe ratio of $2: 1$ to 3:1 and $\mathrm{a} \mathrm{Cr}_{2} \mathrm{O}_{3}$ content of 35 to $50 \%$ by weight.

\section{INTERPRETATION AND DISCUSSION}

Using the regional Quaternary framework of the Port au Port Bay area (Grant, 1991; Forbes $e t$ al., in press) and the observed distribution of $\mathrm{Cr}$ in Port au Port Bay, a conceptual model depicting the paleoenvironmental evolution and succession of chromite-bearing sedimentary facies is proposed (Fig. 10).

\section{Stage 1. Sea level maximum (+45 m): 14 ka B.P.}

Around 14 ka B.P. a large chromite-bearing, outwash plain/marine-limit, delta complex was formed near the mouth of Fox Island River by proglacial meltwater. The outwash complex extends over an area of about $29 \mathrm{~km}^{2}$ of which 10 $\mathrm{km}^{2}$ occurs within the present offshore (Fig. 10A). Glaciomarine muds accumulated in the deeper waters off the river mouth and in Two Guts Pond embayment. 


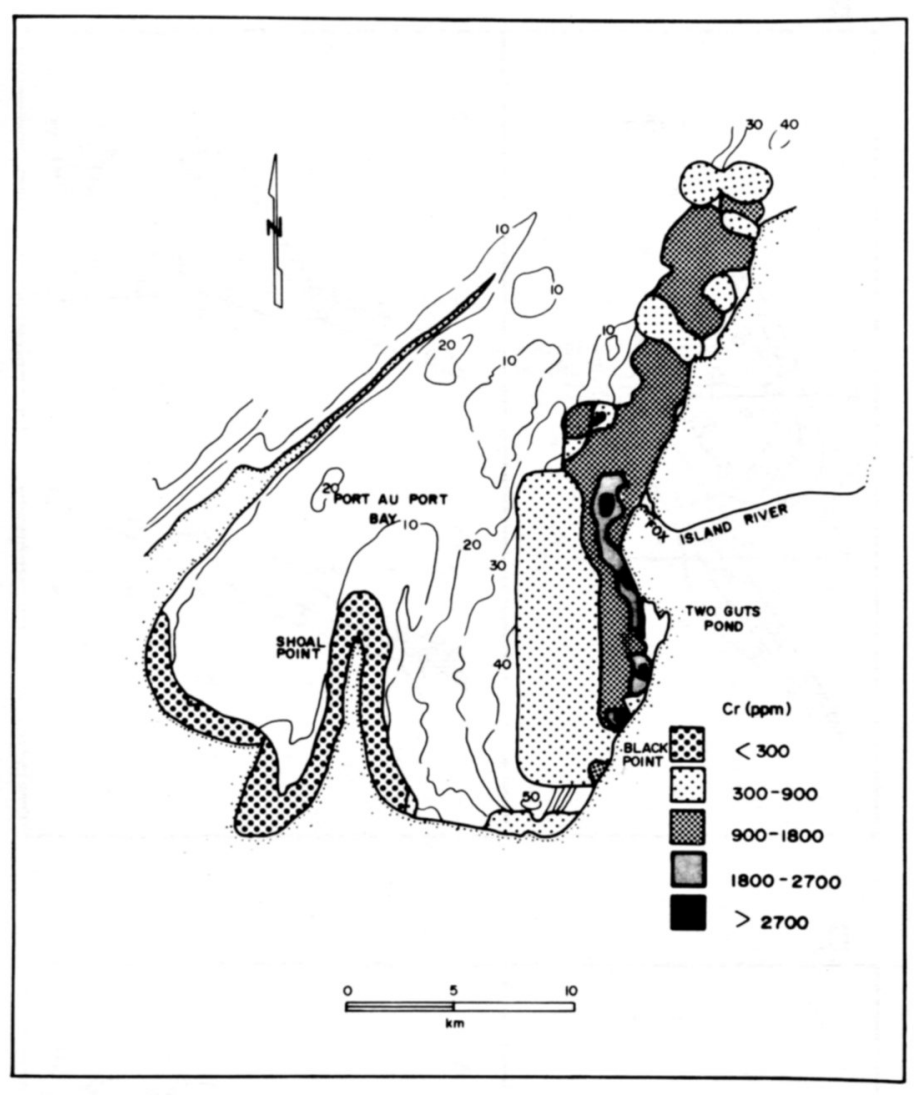

Fig. 9. Distribution of $\mathrm{Cr}$ (ppm) within the surficial sediments.

\section{Stage 2. Sea level regression (+ $45 \mathrm{~m}$ to $-20 \mathrm{~m})$ : 14-9.5 ka B.P.}

Postglacial relative sea-level fall resulted in base level lowering and fluvial incision of chromite-bearing, fluvial and glacial-fluvial sediments in the Fox Island River valley (Emory-Moore et al., 1988; Fig. 10B). An erosional lag and wave cut terraces developed on the surface of the outwash delta as it was reworked by the regressing sea. Significant volumes of chromitiferous sediment entered Port au Port Bay through Fox Island River, transported southward and deposited in coastal bars and terraces bordering Two Guts Pond. Wave energy would have been greatest during the highest phases of sea level because of the submergence of Long Point and increased coastal exposure.

Stage 3. Sea level minimum (-20 m to $-25 \mathrm{~m})$ : $9.5 \mathrm{ka} \mathrm{B.P.}$

As sea level continued its relative fall, the sills in Port au Port Bay were subaerially exposed and East Basin became a shallow lake (Fig. 10C). With the energy level substantially decreased during this lacustrine phase, sediment discharging from the mouth of Fox Island River began to aggrade, forming a series of delta topset and forset beds (Fig. 10C; Forbes et al., in press). Sediment accumulation around Two Guts Pond was substantially reduced and finer-grained sediment deposited.

\section{Stage 4. Sea level transgression $(-25 \mathrm{~m}$ to 0$)$ : $9.5 \mathrm{ka}$ B.P. to present}

Fluvial sediment supply was substantially reduced during coastal submergence, from about $9.5 \mathrm{ka}$ B.P. to present (Fig. 10D). With a rise in fluvial base level, infilling and aggradation of sediment in the lower reaches of the Fox Island River valley was accompanied by a significant decrease in the volume of sediment flushed offshore. In addition, extensive downcutting of fluvial sediments in early postglacial times resulted in armouring of the riverbed with a coarse gravel lag (as it is today), thereby reducing sediment availability.

The principal supply of $\mathrm{Cr}$-bearing sediment during the sea level transgression has been, and continues to be, the coastal erosion of reworked outwash sediment bluffs exposed along the shoreline at, and to the south of, Fox Island River. The net movement of sediment by longshore currents appears to have remained southward throughout the sea level transgression with deposition of chromitiferous sediment restricted to the coastal bars and terraces centred on the Two Guts Pond embayment. Remnants of the regressive terraces developed within the Two Guts Pond embayment are preserved.

It is clear that since deglaciation, chromite-bearing sediments have been reworked by glaciofluvial, fluvial and marine processes. The sedimentary facies in the study area that are most likely to host detrital chromite include: fluvial sediments of the Fox Island River, the large outwash plain and marine-limit delta occurring near the mouth of Fox Island River, the erosional lag blanketing the outwash delta, the onlapping lacustrine deltaic complex deposited during the sea level lowstand off the mouth of Fox Island River, and the coastal bars and terraces bordering the Two Guts Pond embayment.

Glacial outwash and deltas are not generally favourable environments for placer formation because of the excessively high rates of sediment accumulation and, in the case of the present study area, the relatively low energy of the marine setting. Perhaps the highest concentration of chromite might be expected to be found in the erosional lag blanketing the outwash delta as marine reworking and sediment deflation generally serve to concentrate heavy minerals by processes of grain entrapment. The concentration of $\mathrm{Cr}$ in the erosional lag ranges from 800 to 3400 ppm.

Beach placers are best developed in the supratidal zone of high energy coastal beaches. The coastal bars and terraces occurring within the Two Guts Pond embayment were, however, deposited in a relatively sheltered, low energy setting. The highest wave energies in the Two Guts area were probably realised soon after deglaciation, when sea levels were at their highest, and the exposure to waves from the northwest consequently greatest. The raised terraces warrant closer examination as the grades of four samples were relatively high, ranging from 1200 to $10300 \mathrm{ppm} \mathrm{Cr}$. The $\mathrm{Cr}$ 
A.

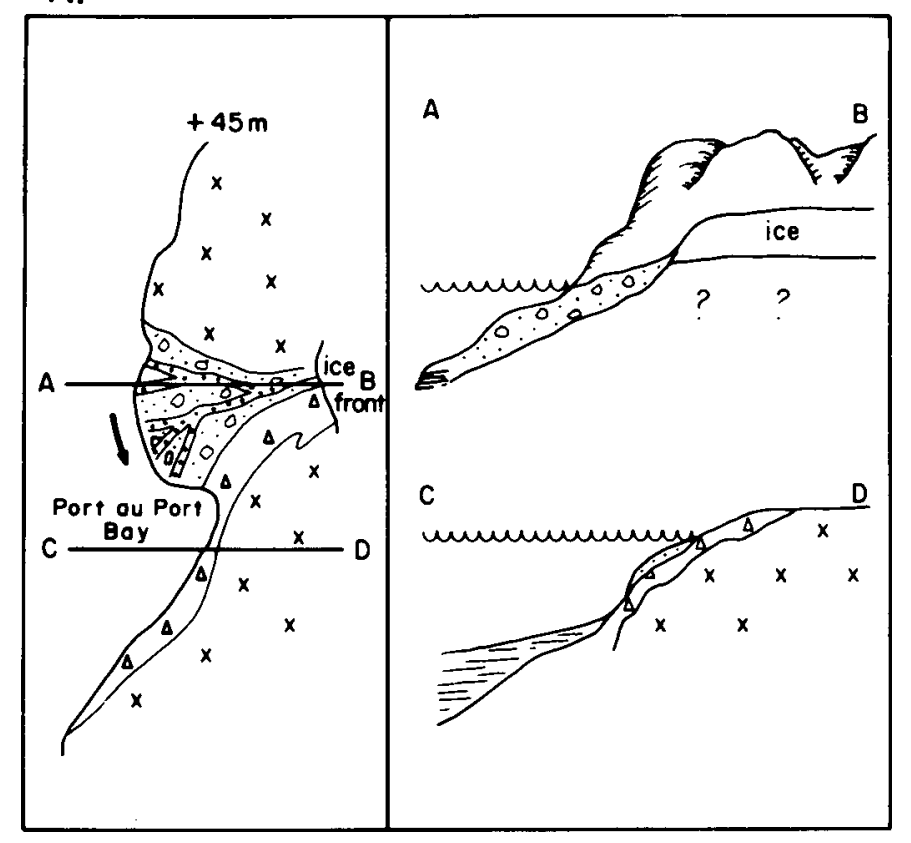

C.
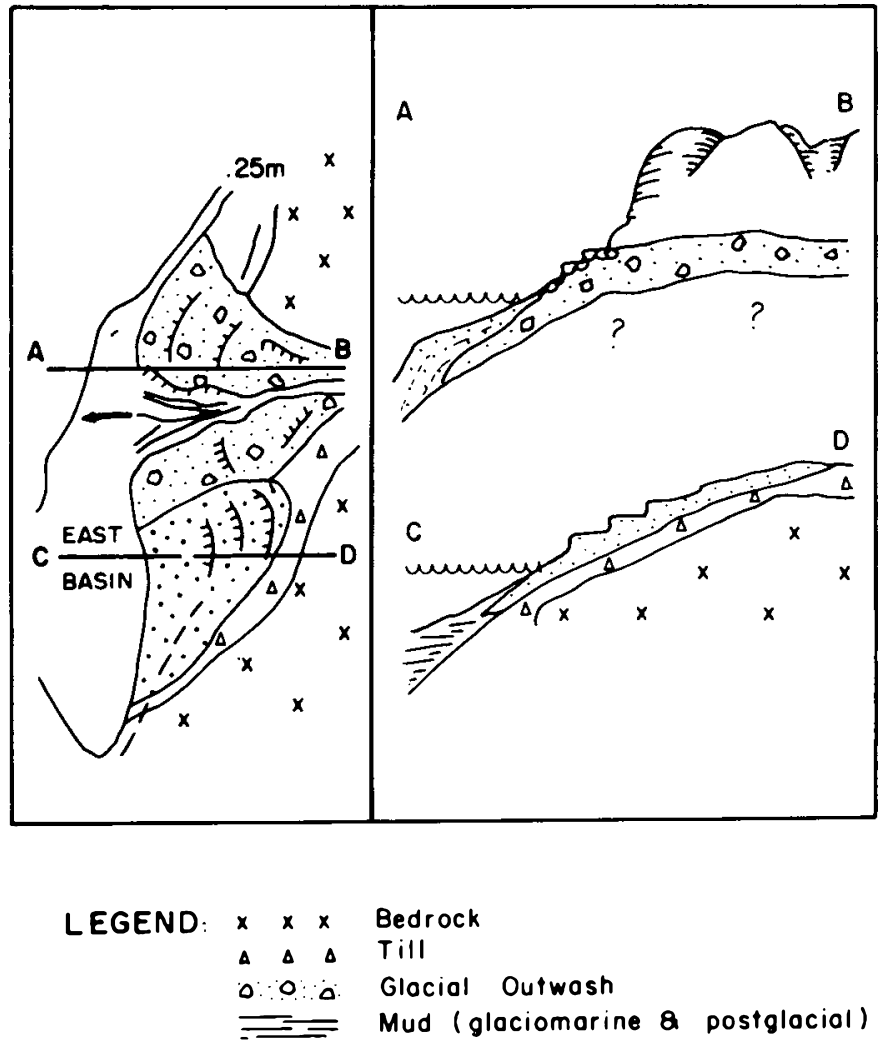

B.

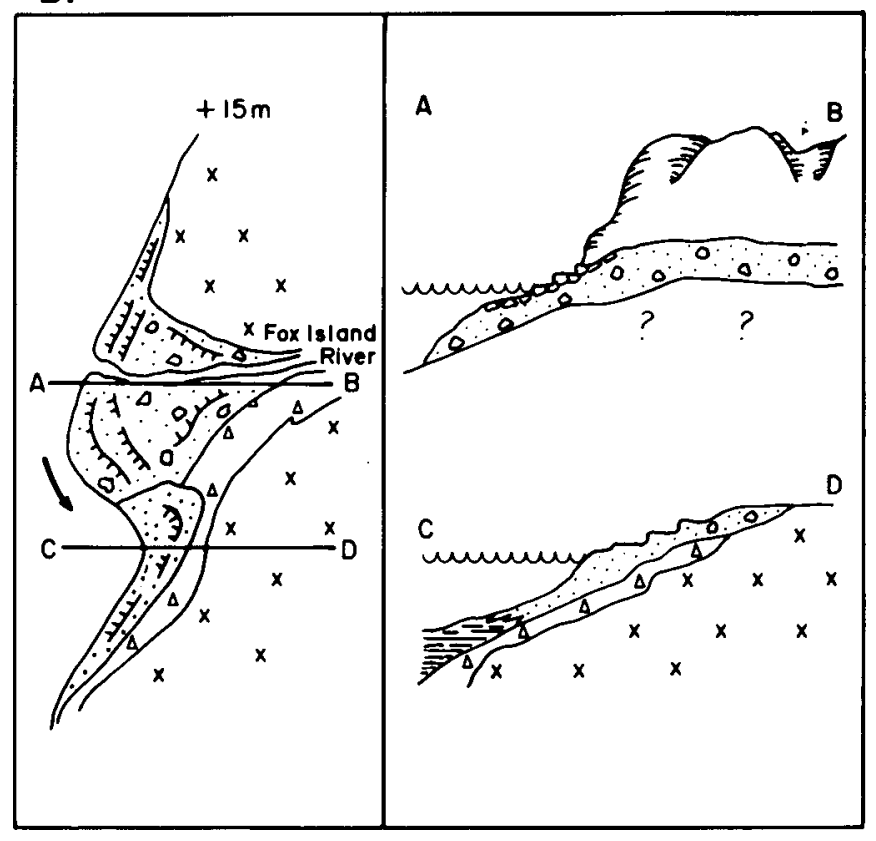

D.

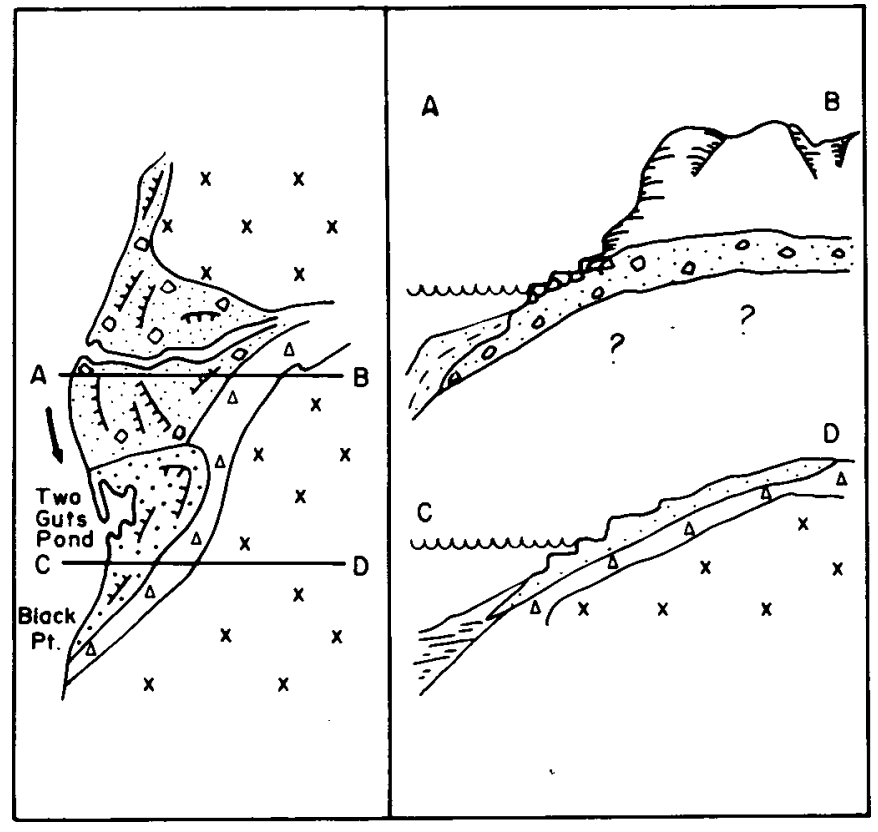

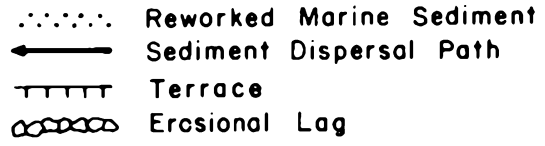

Fig. 10. Paleoenvironmental evolution and succession of chromite-bearing sedimentary facies.

grades of the surficial seabed sediments of fshore of Two Guts Pond range from 1100 to $3600 \mathrm{ppm}$ and may reflect the grade of preserved submerged terraces.

In conclusion, although the sediment around Fox Island River and the Two Guts Pond embayment contain detrital chromite, only minor enrichment by marine processes beyond what is observed in the riverbed and out wash sediments has transpired. Given the apparent availability of mineralized detritus, the relatively low wave energy of the Port au Port Bay seems to be the primary constraint on placer formation. 
The nearshore and emerged marine sediment suite may be expected to contain high total volumes of chromite, albeit at a low grade.

\section{Acknowledgements}

The beach and nearshore sediment sampling programs described herein were undertaken on behalf of International Corona Corporation and Canchrome Mines Limited as part of an ongoing evaluation of the marine placer chromite potential of the area. The authors acknowledge the kindness of International Corona Corporation and Canchrome Mines Limited in releasing the assay data for publication.

Mr. D. Christian of C-CORE was responsible for the logistics for both field programs. Mr. A. Simms of C-CORE helped with the statistical analysis of sediment data. Ms. D. King drafted the figures for this paper. Valuable reviews of the manuscript were provided by D.R. Grant and G.B. Fader.

Cawood, P.A., Williams, H., O'Brien, S.J., and O'Neill, P.P. 1988. Geologic cross-section of the Appalachian orogeny. Geological Association of Canada, St. John's, Newfoundland, Field Trip Guidebook, Trip $1 \mathrm{~A}$.

Dunsworth, S., Calon, T., and Malpas, J. 1986. Structural and magmatic controls on the internal geometry of the plutonic complex and its chromite occurrences in the Bay of Islands Ophiolite, Newfoundland. In Current Research, Geological Survey of Canada, Paper 86-1A, pp. 471-482.
Emory-Moore, M., Solomon, S.M., and Dunsmore, D. 1988. Placer potential of Fox Island River and east-central Port au Port Bay: a preliminary assessment. Newfoundland Department of Mines and Energy, Current Research, Report 88-1, pp. 343-355.

Forbes, D.L., SHA W, J., and EdDY, B.G. In press. Late Quaternary sedimentation and the postglacial relative sea level minimum in Port au Port Bay and vicinity, west Newfoundland. Atlantic Geology.

GrANT, D.R. 1987. Quatemary geology of Nova Scotia and Newfoundland (including the Magdalen Islands). International Union for Quaternary Research, XII INQUA Congress, Ottawa. Excursion Guidebook A-3/C-3, National Research Council Publication 27525, 62 p.

1991. Surficial geology, Stephenville-Port au Basques. Geological Survey of Canada, Map 1737A, scale 1:250,000.

HiLL, P.A. and Ruest, A.E. 1980. Heavy minerals and metals in Port au Port Bay, Newfoundland: a reconnaissance. Economic Geology, 46, pp. 961-970.

KARson, J.A. 1979. Geological map $(1: 25,000)$ and descriptive notes on the Lewis Hills massif, western Newfoundland. Geological Survey of Canada, Open File 62B.

Williams, H. 1985. Geology, Stephenville map area, Newfoundland. Geological Survey of Canada, Map 1579A, scale 1:100 000 .

Woodward-Clyde Consultants. 1982. A study of the accessibility of three small craft harbours - western Newfoundland. Technical Report prepared for Department of Fisheries and Oceans, Northwest Atlantic Fisheries Centre, White Hills, St. John's, Newfoundland. 